\title{
REPEAT USE OF UNEMPLOYMENT INSURANCE
}

\author{
Bruce D. Meyer \\ Dan T. Rosenbaum
}

Working Paper 5423

\section{NATIONAL BUREAU OF ECONOMIC RESEARCH 1050 Massachusetts Avenue \\ Cambridge, MA 02138 \\ January 1996}

We would like to thank Rebecca Blank, Peter Meyer, Carolyn Moehling and seminar participants at the NBER Summer Institute, the Berkeley-NSF Symposium, Michigan, and Northwestern for their comments. This work has been supported by the Sloan Foundation and the NSF through SBR-9310280 and through a Research Training Fellowship in Urban Poverty funded by the NSF and Northwestern. This paper is part of NBER's research programs in Labor Studies and Public Economics. Any opinions expressed are those of the authors and not those of the National Bureau of Economic Research.

() 1996 by Bruce D. Meyer and Dan T. Rosenbaum. All rights reserved. Short sections of text, not to exceed two paragraphs, may be quoted without explicit permission provided that full credit, including $($ ) notice, is given to the source. 


\title{
REPEAT USE OF UNEMPLOYMENT \\ INSURANCE
}

\begin{abstract}
We examine the extent to which unemployment insurance (UI) insures workers against unforeseen events or subsidizes firms and workers engaged in temporary layoffs. Our main source of data is a 5-year panel of UI administrative records from five states. While most claimants receive UI only once during this period, nearly forty percent of claims go to those individuals with three or more years of receipt during the 5-year period. Most repeat recipients are concentrated in seasonal industries and are laid off by the same employer each time. We also find that middle-aged and high-paid workers are more likely to be repeat recipients, suggesting that workers in bad jobs are not the individuals who repeatedly receive UI.
\end{abstract}

Bruce D. Meyer

Department of Economics

Northwestern University

Evanston, IL 60208

and NBER
Dan T. Rosenbaum

Department of Economics

Northwestern University

Evanston, IL 60208 


\section{Introduction}

One of the central empirical questions about unemployment insurance (UI) is the extent to which UI insures against unforeseen events or subsidizes certain firms and workers engaged in temporary layoffs. Government provision of insurance against unforeseen layoffs can be justified by the absence of a well-functioning private unemployment insurance market due to both aggregate recession risk and adverse selection by workers and firms. On the other hand, subsidies to workers and firms with frequent and predictable layoffs lead to distortions of employment in favor of industries and firms with unstable employment, such as seasonal ones. We shed light on the relative importance of these two phenomena by examining the repeat use of UI using administrative data from a large sample of workers. The specific issues we investigate include what fraction of UI benefits are received by repeat participants and whether employers use UI to subsidize long-term employees during periods of low demand. We show which industries exhibit the most repeat UI participation and if these industries are seasonal. Finally, we examine whether the workers that receive UI almost every year are repeatedly displaced, and are disproportionately young, less educated, and low paid.

Previous research has focused on the subsidy to particular firms and industries or has emphasized temporary layoffs and recalls. Anderson and Meyer (1993) show the extent and persistence of the UI subsidies to firms and industries due to incomplete experience rating. ${ }^{1}$ Katz and Meyer (1990) show that almost two-thirds of UI recipients

\footnotetext{
${ }^{1}$ Earlier work on industry level subsidies includes Becker (1972) and Munts and Asher (1981).
} 
expect to be recalled and nearly half return to their former employer. There has been almost no work on repeat use of UI in the United States, ${ }^{2}$ though there has been work by Corak (1993) and Corak and Pyper (1995) showing that Canadians exhibit a high frequency of repeat UI participation. Related research on other social insurance programs, in particular Aid to Families with Dependent Children (AFDC) has emphasized repeat use (see Ellwood, 1986 and Blank and Ruggles, 1994).

Perhaps due to data limitations, repeat use of unemployment insurance in the U.S. has received little attention. This study makes use of longitudinal administrative data for a large sample of claimants in five states over a 5-year period. These data capture all of the claimants' experiences with the UI program during the period July 1979 to June 1984: Besides providing accurate information on the timing of UI receipt, the administrative data avoid the underreporting of benefits that appears to plague household surveys (see Hutchens, 1981). The plan of the paper is as follows. Section 2 describes our data, while Section 3 reports our main results. Section 4 describes ordered logit models for the rate of repeat UI participation. Section 5 summarizes results from a 14-year panel from one state, and Section 6 concludes.

\section{Data}

Our data come from five states that participated in the Continuous Wage and

${ }^{2}$ Murray (1972) describes some studies of single states in the 1960's. A recent paper, McCall (1995), is more closely related to the takeup literature and examines the sources of repeat receipt among those who separate and are monetarily eligible. 
Benefit History (CWBH) project between July 1979 and June 1984. The five states-Georgia, Idaho, Missouri, Pennsylvania, and Washington--are the only states participating in the CWBH project for which there are data for the entire 5-year period. These states are roughly representative of the United States in terms of benefit levels and the degree of experience rating. ${ }^{3}$ Our random sample is longitudinal, i.e., it includes all records for a given individual during our sample period. ${ }^{4}$ We also use additional data that we recently obtained for Washington state giving us a 14-year panel for one state for the period July 1979 to June 1993.

The data come from three sources: quarterly wage records, UI claims records, and a supplementary questionnaire. The quarterly wage records are UI administrative records for each quarter of the sample period and include the dollar amount of wages received by the employee, the firm's four-digit standard industrial classification (SIC), and a firm identifier - the federal employer identification number (FEIN).

The second source of data, the UI claims records, is also administrative. These records consist of information on UI claim dates, base period and high quarter earnings, ${ }^{5}$ UI check dates, UI check amounts, FEIN's, SIC codes, and some demographic

\footnotetext{
${ }^{3}$ In terms of experience rating, our states are spread throughout the distribution, though on average they are less tightly experience rated than average largely because Washington was not experience rated at all during this time period. Topel (1990) provides summary measures of the degree of experience rating for 4 of our 5 states, while Card and Levine (1992) provide summary measures for 3 of our states.

${ }^{4}$ The sample was chosen using social security number ending digits. The state sampling rates are Georgia (5\%), Idaho (10\%), Missouri (5\%), Pennsylvania (1\%), and Washington $(5 \%)$.

${ }^{5}$ The base period is the first four of the five calendar quarters prior to the quarter of claim. High quarter earnings are earnings during the best quarter of the base period.
} 
information such as age and gender.

The third source of data is a questionnaire which was administered by UI officials at the time of a claimant's initial claim. This unique part of the CWBH program provides additional demographic variables and is still only administered by one or two states. $^{6}$ We only include in our sample those benefit years in which positive benefits are paid. ${ }^{7}$ Our final sample of benefit years includes 199,066 observations from 122,421 claimants.

\section{Main Results}

The claim data we use for most of our results have been summarized into benefit year records. A benefit year is the 52-week period beginning when a claimant files a new initial UI claim. As well as being our main unit of analysis, the benefit year is the administrative period during which an individual is qualified for benefits after filing. Since a benefit year captures a claimant's entire 52-week UI experience, it potentially encompasses multiple spells of UI receipt. On average there are 2.7 spells of UI receipt in each benefit year.

We also examine spells of UI receipt, but we prefer our benefit year measure because average spell lengths differ greatly across industry and across people with

\footnotetext{
${ }^{6}$ The response rate to some of the questions is much less than one-hundred percent. We discuss this more below when these variables are used.

${ }^{7}$ This exclusion reduces our sample size from 235,544 to 199,074 . We also excluded 8 observations which had a "sixth" benefit year in our 5-year sample.
} 
different numbers of spells. We illustrate this point below after presenting the frequency of repeat use by benefit year. In particular, there are certain industries and firms that have a large number of short spells that would distort any picture based on spells. A benefit year also has the advantage that it must start with a new claim, while a new spell can be the result of someone returning from vacation, recovering from illness, or restarting job search.

Tables 1 and 2 report the distribution of the number of benefit years claimed by individuals in our sample during a 5-year period. We report both numbers for each state and total figures using the sampling weights for each state. There are two main questions we would like to answer with the distribution of the number of claims (we use claim and benefit year interchangeably from here on). We would like to know first, if most people who ever receive UI have multiple claims, and, second, if the average person receiving UI at a point in time has multiple claims during our 5-year window. These two questions may have very different answers. We should note that the latter question is the same as asking whether most benefits go to workers who make multiple claims during the five years.

Table 1 gives the percentage of people with a given number of claims. This table indicates that most people who ever receive UI in our 5-year period have only one claim. For example, 22,506 of the 35,479 sampled UI recipients in Georgia receive benefits in only one of the five years. The average percentage with one claim over the five states is just under 60 percent. The percentage is a bit higher than 60 percent in Georgia, Missouri and Washington (63.4, 61.4 and 64.3 percent, respectively) and a bit lower in 
Idaho and Pennsylvania (57.5 and 56.5 percent, respectively). Thus, it appears that most UI recipients use the UI program as a source of income insurance during rare bouts of unemployment. One might soften this conclusion somewhat since our sample period (1979:3-1984:2) includes two recessions. Since we disproportionately sample the cyclically unemployed, the Table 1 numbers might overstate the percentage of one time use of UI. Our 14-year analysis of Washington state described below provides little evidence either way on whether such a bias is present; for the most part, the extent of repeat use only changes slightly from year to year. Probably more importantly, since many people are in a given state's labor force for only part of our time window due to in-migration, labor market entry, out-migration, retirement, etc. our numbers are likely to be further biased in the direction of higher one-time participation.

A different picture emerges if one asks whether those people who receive UI at a point in time are likely to be repeat recipients. In Table 2 we see that in Georgia even though over 60 percent of UI recipients are one-time users, only 22,506 of the 54,951 benefit years ( 41.0 percent) are from recipients with one benefit year in our 5 -year window. Again, Idaho and Pennsylvania exhibit somewhat greater repeat use. In Idaho over two-thirds (67.6 percent) of the entire states' benefit year total comes from recipients with two or more benefit years. Over one quarter ( 25.5 percent) of the benefit years are from those with four or more benefit years. The percentages for Pennsylvania are 67.9 and 22.3 , respectively. Overall, $64.2,37.5$, and 18.3 percent of benefit years are attributable to people with at least two, three, or four years of receipt, respectively. Similar to the findings by Ellwood (1986) for AFDC, even though most of the 
beneficiaries in our sample experience only one benefit year, most of the UI claims are made by those with multiple benefit years.

Since there appears to be only a weak relationship between the number of benefit years claimed and the dollars per benefit year claimed, the numbers of Table 2 approximate the fraction of UI resources consumed by repeat recipients. While the bottom two lines of Table 2 show that the per claim average dollar amount and number of weeks of benefits paid out does decrease somewhat with the number of claims, the decrease is not large. Consequently, we conclude that repeat use consumes a large proportion of a state's UI resources.

\section{SPELLS OF UI RECEIPT}

Before continuing, it is useful examine the analogue of Table 2 if our unit of analysis is a spell. Table 3 reports the last 3 lines of Table 2, but for spells rather than benefit years. Here we see that nearly half of all spells are accounted for by those who have seven or more spells in the 5-year period. However, we also see that the average dollar amount and number of weeks of benefits paid out per spell drops dramatically with the number of spells. On average, someone with ten spells consumes much less than ten times the UI resources of someone with one spell. This concentration of many short spells in certain individuals and firms motivated our use of the benefit year.

\section{ADJUSTED MEASURES OF REPEAT USE}

The raw numbers of Table 2 differ from an ideal measure of repeat use for at 
least two reasons. First, as mentioned above, many individuals are not at risk to repeatedly receive UI in a given state during our entire 5-year period because they are in the state and the labor force for only part of the period. Even initial labor force entry and retirement by themselves imply that a substantial fraction of our sample could not have five benefit years. Second, part of the repeat use that we observe is due to chance; even randomly distributed claims will lead to some individuals receiving UI multiple times. To correct for the first problem we exclude individuals who have four consecutive calendar quarters without earnings. To correct for the second problem we subtract from these claim numbers the counts that are implied by a random allocation of claims across individuals. Specifically, we assume an equal and constant claim probability for all individuals in a given state, with this claim probability determined by equating the actual and predicted number of benefit years in each state. ${ }^{8}$

Table 4 reports the results of the adjustments to the Table 2 percentages. The two adjustments work in opposite directions. Overall, excluding those with absences from a state's workforce of more than one year raises the fraction of claims due to those with more than three claims in five years from 37.5 to 42.4 percent. Subtracting off the number due to those with claims that would be expected by chance leaves us with 34.9 percent. These results also demonstrates quite unambiguously that either the yearly

${ }^{8}$ Formally, we assume homogeneity and no state dependence. The yearly claim probability is given by: yearly claim probability $=$ total benefit years $/\left(5^{*}\right.$ sampling rate*average employment). For our 5 states in alphabetical order the claim probability is $0.105,0.140,0.106,0.137$, and 0.117 . The overall average is 0.122 . 
claim probability is not equal for all individuals or it is not constant. ${ }^{9}$ Consequently, we conclude that the data exhibit a great deal of repeat UI participation.

\section{REGULARITY IN THE NUMBER OF WEEKS RECEIVED}

While certain people seem to receive UI year after year, the number of weeks of benefits that these individuals receive may change from year to year. To examine this issue, we perform a variance decomposition of the number of weeks of benefits received in a benefit year. ${ }^{10}$ We allow separate influences of state, industry, individual, and an iḍiosyncratic term which captures all other factors. This last component of the variance is the largest, accounting for about two-thirds of the overall variance in weeks of UI in a benefit year. This result indicates that even when an individual receives benefits in most years, the length of time spent on the program is likely to be uncertain to the individual.

\section{EXPLANATIONS FOR REPEAT USE}

There are two main explanations for repeat use: temporary layoffs and job holding problems. These two explanations have different implications for UI policy. The first explanation, temporary layoffs and recalls, attributes repeat use to some combination of

\footnotetext{
${ }^{9}$ In other words, our data exhibit either worker heterogeneity, state dependence, or both.

${ }^{10} \mathrm{We}$ use the SAS VARCOMP procedure and the MIVQUE0 method of calculating the variance components.
} 
seasonality or other frequent demand fluctuations and the implicit subsidy to layoffs provided by incomplete experience rating. In many cases a firm's demand for labor varies over the year resulting in periodic pressure to lay off workers. These workers are then recalled when labor demand rebounds. In some industries these layoffs and recalls may not be confined to certain parts of the year, but for others like construction, agriculture, and fishing, layoffs follow a predictable seasonal pattern. Employers and employees may reach an understanding that allows workers to return to their former employers after such a layoff. Medoff (1979) argues that unions facilitate this practice and that senior employees might welcome a layoff if it is of short duration and recall is nearly certain. These layoffs may be encouraged even in the absence of underlying seasonality by incomplete experience rating. ${ }^{11}$ Incomplete experience rating means that a firm may pay less than the full UI costs of layoff. In this situation, the cost to a firm (in increased payroll taxes) of a temporary layoff may be less than the value of the UI benefits to its workers. In our states, the vast majority of firms pay much less than the full UI costs of their marginal layoffs (see Anderson and Meyer, 1994 and 1995 for more detail on four of our five states).

We refer to the second explanation for repeat use as job holding problems. With this term we intend to capture the idea that some workers may be unable to hold a permanent job and endure stretches where they are repeatedly permanently laid off. We might expect those with job holding problems to be disproportionately young, low-paid,

\footnotetext{
${ }^{11}$ This argument has been elaborated by many authors including Baily (1977), Feldstein (1976), Topel (1983), Anderson (1993), Card and Levine (1994), and Anderson and Meyer (1995).
} 
and nonwhite. However, we might also expect that those with the very lowest skills do not appear on the UI rolls due to insufficient earnings. Workers who work sporadically may fail to qualify for UI and thus may never enter our sample or may receive UI only once or twice in our 5-year window. We should note, though, that the minimum earnings requirements for UI eligibility are not especially high. While the requirements vary from state to state, the lowest earnings requirement in the high quarter was just under $\$ 400$ (1990 dollars) in Missouri, while the highest was just over $\$ 1100$ in Idaho. ${ }^{12}$

\section{THE PREVALENCE OF TEMPORARY LAYOFFS}

To shed light on the relative prevalence of temporary layoffs and job holding problems among repeat recipients, we report in Table 5 the percentage of workers with different numbers of UI claims by the number of different firms that laid them off. ${ }^{13}$ This table shows that most repeat recipients were repeatedly temporarily laid off by the same firm. Over half of the workers with three or more benefit years left the same firm each time. Over 80 percent of the workers with three or more benefit years were laid off by the same one or two employers during the sample period. The striking prevalence of

\footnotetext{
${ }^{12}$ Washington requires 680 hours of base period employment for UI eligibility. We should point out that quits and dismissals due to misconduct disqualify an individual from receiving UI. Overall, only about one-third of the unemployed receive UI (Blank and Card, 1991), though an important reason for this low rate is a low takeup rate among eligibles.

${ }^{13}$ To determine the employer for a particular benefit year observation we use the first nonmissing FEIN from the following sources in order: (1) the quarterly wage record for the quarter prior to the quarter of the benefit year beginning, (2) the quarterly wage record for the quarter two quarters prior to the quarter of the benefit year beginning, and (3) the UI claim record.
} 
long-term attachment to the same employer among repeat recipients provides strong evidence that a substantial fraction of repeat use is due to temporary layoffs, probably induced by some combination of seasonality and incomplete experience rating. ${ }^{14}$

\section{THE IMPORTANCE OF SEASONALITY}

To further determine whether repeat receipt is associated with seasonality we examine which industries have a disproportionate share of the repeat recipients and whether these industries also have seasonal variation in employment. In Table 6 we report the industry distribution of those with a given number of benefit years in our 5year period, as well as the industry distribution of the entire workforce. ${ }^{15}$ We also report a measure of seasonality defined as the difference between the 5-year average employment in the best and worst quarters divided by average employment over all twenty quarters. Table 6 clearly demonstrates the concentration of UI recipients with multiple benefit years in particular, often seasonal, industries. From the table we see that construction and the first manufacturing group, which includes food, tobacco, textiles, apparel, and lumber industries, account for over 47 percent of the UI

\footnotetext{
${ }^{14}$ We recalculated Table 5 excluding construction workers who are often thought of as more attached to a union than a firm. The number of employers per worker was lower in this restricted sample, but not dramatically lower.

${ }^{15}$ With a few exceptions, we follow the SIC Division classification system. We combine agriculture and mining into one category, and finance, insurance, and real estate (FIRE), services, and public administration into another category. We split the manufacturing division into two parts, the first of which includes food, tobacco, textiles, apparel, and lumber, and a second which includes all other manufacturing industries.
} 
beneficiaries with three or more benefit years, but less than 14 percent of overall employment. These industries have the highest seasonality measures other than agriculture. While individual 2-digit industries are not reported, the apparel industry alone contributes 12.5 percent of the recipients with three or more benefit years, while only supplying 2.3 percent of the employees covered by UI in these five states. The apparel industry is an interesting case in that it is not very seasonal, at least not at the quarterly level. ${ }^{16}$ Agriculture, mining, and other manufacturing have higher percentages as the number of benefit years received rises, and agriculture and mining are especially seasonal. Conversely, transportation, communication, wholesale trade, retail trade and other industries (2-digit SIC's 52-98) have lower percentages as the number of benefit years received increases. The decline for retail trade and other industries is precipitous: these industries account for over 52 percent of all employees, but only 12 percent of those with three or more benefit years.

Within the individual states the concentration of repeat recipients in particular (mostly seasonal) industries is even more dramatic. At the 2-digit SIC industry level, in Georgia, the apparel and textile industries alone account for almost half of the recipients with three or more benefit years, though again, these industries are not seasonal by our measure. For Idaho, over 40 percent of those with three or more benefit years come from the notably seasonal food and lumber industries. Missouri, Pennsylvania, and Washington exhibit more industry diversity in their repeat participation. In Missouri, the six 2-digit industries contributing the largest number of repeat claimants--transportation

${ }^{16}$ The textile industry is often described as seasonal (see Murray, 1972 for example). 
equipment, leather, apparel, and the three construction industries--account for just under half of the persons with three or more benefit years. All of these industries except apparel have very high seasonality measures. Pennsylvania's top three repeat use industries, apparel, special trade contractors, and primary metal (steel) manufacturers contribute a little over a third of the state's individuals with three or more benefit years. Lastly, in Washington the food, lumber, and the three construction industries, all of which are very seasonal, contribute over half of the persons with three or more benefit years. As expected, we find that a few mostly seasonal industries are responsible for most repeat use, though the industries differ somewhat across states.

To gauge the overall importance of seasonality, we also examined the correlation between our seasonality measure and repeat use using the eight industry groups in our five states as individual observations. The correlation between our seasonality measure and the number of individuals with 3-5 claims divided by total employment is .41 (with a p-value of .009). Thus, there is strong overall support for seasonality being a key source of repeat use.

\section{Ordered Logit Results}

In order to estimate the separate effects of a large number of individual and firm characteristics, we estimated ordered logit models for the number of claims. Since the individual demographic variables are only available for those people with at least one UI claim, we estimate the total number of claims conditional on the receipt of benefits in a 
given year. In particular, we restrict our sample to 1980 recipients and estimate the number of claims during our 5-year period. ${ }^{17}$ These estimates allow us to determine the firm and individual characteristics associated with repeat use. We use a sample of recipients from 1980 because it is as close to an average unemployment year as is available during our sample period. ${ }^{18}$ As in Table 4, to remove from the sample individuals who are not at risk for UI receipt during large parts of the sample period such as interstate movers, retirees, and the long-term unemployed, we exclude individuals who have four consecutive quarters without any earnings during our sample period. ${ }^{19}$ Our initial list of explanatory variables includes dummy variables for gender, race, age, high quarter earnings, state, quarter of benefit year beginning (claim date), and industry. ${ }^{20}$ In the later specifications we add the variables that are more commonly missing, namely marital status and education, leading to a drop in the sample size. ${ }^{21}$

In the first specification, the baseline individual is a white, 35-44 year-old male with high quarter earnings between $\$ 3,000$ and $\$ 4,999$ (1990 dollars). In addition, his

\footnotetext{
${ }^{17}$ We also estimated binary logits for the probability of three or more claims in the 5-year window. The resulting coefficient estimates were extremely similar to those reported, though they were slightly less precise.

${ }^{18}$ The unemployment rates in our five states in 1980 were: Georgia 6.4 percent, Idaho 7.9 percent, Missouri 7.0 percent, Pennsylvania 7.8 percent, and Washington 7.5 percent.

${ }^{19}$ This restriction reduces our sample size from 29,951 to 21,666 (Georgia is already excluded in these counts). We lose another 3,460 observations prior to specification (1) mostly due to excluding those over 55 in 1980.

${ }^{20} \mathrm{We}$ do not include Georgia in these logit equations because its age information is frequently missing and appears to be nonrandomly missing.

${ }^{21}$ Missouri is dropped from the third specification, since it does not record education.
} 
benefit year begins between January and March, and he works in the Pennsylvania service sector. In the second specification, the baseline individual is unmarried, and in the third specification he has only a high school education. In Table 7, we report for each variable its mean, estimated coefficient, standard error, and the estimated average effect of changing the variable from zero to one on the probability of three or more claims.

While attributes such as low earnings, being young, nonwhite and having little education are in general associated with a higher likelihood of unemployment, the probability of repeat UI use is not related in the expected way to these attributes. In fact, some of the attributes thought to indicate a good job and a skilled worker are associated with a high probability of repeat use. While job holding problems are clearly responsible for a major part of repeat use, there is surprising evidence that those who repeatedly use UI often have good jobs and some might prefer to be laid off and receive UI for part of the year.

The Table 7 estimates give mixed evidence for the effects of the background characteristics, gender, marital status, and race on repeat use. Nonwhites and married women are significantly more likely to repeat, when one does not control for education. With nonwhites, repeat use is likely due to bad job opportunities, though with married women it may be due to a desire to regularly work part of the year. The effect of the education variables show that those with less education, and likely worse job opportunities, are more likely to repeat.

The age and earnings coefficients provide the strongest suggestion that repeat UI 
compensated layoffs may be desired by a substantial fraction of repeat recipients.

Repeat use rises monotonically with age and presumably seniority, indicating that those in a better position to choose their terms of employment (especially in union jobs) are more likely to be repeat UI claimants. Those with the highest quarterly earnings are also significantly more likely to be repeat recipients. The relationship between earnings and repeat use even becomes monotonic once we control for education. The higher earnings of repeat claimants may partly reflect compensating differentials, though such differentials are usually hard to detect. ${ }^{2}$

Table 7 also indicates that Idaho and Pennsylvania have the highest rates of repeat UI use. The quarter of claim variables indicate that those who begin benefit years in the fourth quarter are the most likely to be repeaters, while those beginning in the second quarter are the least likely to be repeaters. This finding supports a seasonal explanation for many of these layoffs as those laid off during the bad weather of the late fall and winter are the most likely to be repeaters.

Given the earlier evidence in Table 6 it is not surprisingly that we find that industry is an influential determinant of repeat UI participation. Workers in the apparel industry are 33 percentage points more likely to have three or more claims than workers in the service sector. The industries that exhibit high repeat UI participation are the agriculture, forestry, and fishing division, the mining and construction divisions, and the food, tobacco, apparel, textiles, lumber, leather, and transportation equipment

\footnotetext{
${ }^{22}$ We also tried ordered logit specifications with the weekly UI benefit amount or the replacement rate as explanatory variables. These variables were not significant and did not appreciably change the other coefficients.
} 
manufacturing groups. While not as great as these last industries, several other industries have much higher rates of repeat UI participation than the service sector including primary metal industries (steel), other manufacturing groupings and the transportation/communications and wholesale trade divisions. The retail trade and public sector are not significantly different than the service sector, whereas finance, insurance, and real estate are much less likely to have repeat UI recipients than the service sector.

\section{Some 14-Year Panel Results from Washington State}

In this section we examine two additional issues: the extent of repeat UI use over a longer time horizon and the cyclicality of repeat use. While not available for other states, data obtained through a special confidentiality agreement allow us to extend our panel through 1993:2 for Washington state. ${ }^{23}$ This 14-year panel indicates that just under half ( 49.2 percent) of benefit years in a 14-year period are attributable to those with five or more benefit years. ${ }^{24}$ These individuals have an average of 7.4 benefit years of receipt. Thus, a substantial fraction of UI resources go to those who repeatedly receive UI.

As stated earlier, one might expect that the extent of repeat use would be lower in a recession if a large fraction of the unemployed are those who are unlikely to lose their

\footnotetext{
${ }^{23}$ We thank Wayne McMahon and Wendell Wilson of Washington State Employment Security for providing the data.

${ }^{24}$ In this analysis we excluded those individuals with eight consecutive quarters without earnings and those with earnings in less than half of the quarters covered.
} 
jobs in better times. We were unable to find much evidence either confirming or disproving this hypothesis. Repeat use only varied slightly from year to year as the range of the percentage of claims due to those with three or more claims in a 5-year window was 32.7 to 35.1 percent over the period, even though the unemployment rate varied from 4.9 to 12.1 percent. The rate did trend downward over the period as the state unemployment rate fell, but the extent of experience rating also moved dramatically in the same direction and could account for this change.

\section{Conclusions}

Using administrative data from five states between 1979 and 1984, we find that repeat UI use is a prevalent feature of the UI system. Almost forty percent of the benefit years in our sample are from claimants with three or more benefit years in the 5year period. A large fraction of this repeat use is attributable to temporary layoffs as over half of the persons with multiple benefit years in the sample separate from the same employer each time. Certain industries, particularly construction and manufacturing, generate most of the repeat UI use; these two industries account for over three-quarters of those with three or more benefit years but less than one-third of overall employment. At a finer industry level we find that agriculture, forestry and fishing, mining, construction, food, tobacco, apparel, lumber, leather, and transportation equipment exhibit high rates of repeat UI use. In contrast, retail trade, financial, insurance, real estate, services, and the public sector have low rates of repeat UI participation. We find 
strong evidence that the industries with high repeat are those with seasonal variation in employment levels.

We also find that some of the attributes thought to indicate a better job are associated with a high probability of repeat use. There is surprising evidence that those who repeatedly receive UI tend to have good jobs and some may prefer to be laid off and receive UI for part of the year. While nonwhites and those with less education are more likely to be repeat recipients, more senior workers, and those with higher quarterly earnings are more likely to be repeat recipients.

Overall, these results suggest that a substantial portion of UI resources subsidize certain firms and industries rather than provide true insurance. Tighter experience rating most likely would reduce this aspect of repeat use, but in any case would reduce the subsidies to the firms and industries engaged in temporary layoffs. 


\section{References}

Anderson, Patricia M. (1993): "Linear Adjustment Costs and Seasonal Labor Demand:

Evidence from Retail Trade Firms," Quarterly Journal of Economics, 108

(November 1993), 1015-1042.

Anderson, Patricia M. and Bruce D. Meyer (1993): "The Unemployment Insurance

Payroll Tax and Interindustry and Interfirm Subsidies," in Tax Policy and the

Economy 7, edited by James Poterba, M.I.T. Press, pp. 111-144.

Anderson, Patricia M. and Bruce D. Meyer (1994): "The Effect of Unemployment Insurance Taxes and Benefits on Layoffs Using Firm and Individual Data," NBER Working Paper No. 4960.

Anderson, Patricia M. and Bruce D. Meyer (1995): "Using a Natural Experiment to Estimate the Effects of the Unemployment Insurance Payroll Tax on Layoffs, Employment and Wages, Mimeo, Northwestern University.

Baily, Martin Neil (1977): "Unemployment Insurance as Insurance for Workers," Industrial and Labor Relations Review, 30, 495-504.

Bane, Mary Jo and David Ellwood (1983): "The Dynamics of Dependence: The Routes to Self-Sufficiency," Report prepared for U.S. Department of Health and Human Services, Urban Systems Research and Engineering, June 1983.

Becker, Joseph M. (1972). Experience Rating in Unemployment Insurance: An Experiment in Competitive Socialism. Baltimore: The Johns Hopkins University Press.

Blank, Rebecca M., and David E. Card (1991): "Recent Trends in Insured and Uninsured Unemployment: Is There an Explanation?" Quarterly Journal of Economics, CVI (November 1991): 1157-1190.

Blank, Rebecca M., and Patricia Ruggles (1994): "Short-Term Recidivism Among PublicAssistance Recipients," American Economic Review Papers and Proceedings, May 1994, 49-53.

Card, David and Phillip B. Levine (1992): "Unemployment Insurance Taxes and the Cyclical and Seasonal Properties of Unemployment," NBER Working Paper No. 4030, March 1992. 
Card, David and Phillip B. Levine (1994): "Unemployment Insurance Taxes and the Cyclical and Seasonal Properties of Unemployment," Journal of Public Economics 53, pp. 1-29.

Corak, Miles (1993): "Unemployment Insurance Once Again: The Incidence of Repeat Participation in the Canadian UI Program," Canadian Public Policy, 19, 2, June 1993, 162-176.

Corak, Miles and Wendy Pyper (1995): "Workers, Firms, and Unemployment Insurance," Business and Labor Market Analysis Division, Statistics Canada, May 1995.

Ellwood, David T. (1986): "Targeting 'Would Be' Long-Term Recipients of AFDC," Report prepared for U.S. Department of Health and Human Services, Mathematic Policy Research, January 1986.

Feldstein, Martin S. (1976): "Temporary Layoffs in the Theory of Unemployment," Journal of Political Economy, 84, 837-57.

Hutchens, Robert (1981): "Distributional Equity in the Unemployment Insurance System," Industrial and Labor Relations Review, 34 (April 1991), 377-385.

Katz, Lawrence F. and Bruce D. Meyer (1990): "Unemployment Insurance, Recall Expectations, and Unemployment Outcomes," Quarterly Joumal of Economics, 105, November 1990, 973-1002.

McCall, Brian P. (1995): "Repeat Use of Unemployment Insurance," Working Paper, Industrial Relation Center, University of Minnesota.

Medoff, James L. (1979): "Layoffs and Alternatives under Trade Unions in U.S. Manufacturing," American Economic Review, 69, 3, June 1979, 380-395.

Murray, Merrill G. (1972): “The Treatment of Seasonal Unemployment Under Unemployment Insurance," The W.E. Upjohn Institute for Employment Research, April 1972.

Munts, Raymond C. and Ephraim Asher (1981). "Cross-Subsidies Among Industries From 1969 to 1978." Unemployment Compensation: Studies and Research, 277-297.

Topel, Robert H. (1983). "On Layoffs and Unemployment Insurance." American Economic Review 73, 541-559.

Topel, Robert (1990): "Financing Unemployment Insurance: History, Incentives, and 
Reform," in Unemployment Insurance: The Second Half-Century, W. Lee Hansen and James F. Byers, eds., Madison: University of Wisconsin Press, 1990, 108-135. 


\section{Table 1}

Person Weighted Distribution of Claims in 5-Year Window (Row Percentages in Parentheses)

\begin{tabular}{|c|c|c|c|c|c|c|}
\hline \multirow[b]{2}{*}{ State } & \multicolumn{5}{|c|}{ Number of Benefit Years Claimed } & \multirow[b]{2}{*}{ Total } \\
\hline & 1 & 2 & 3 & $t$ & 5 & \\
\hline Georgia & $\begin{array}{c}22,506 \\
(63.4)\end{array}$ & $\begin{array}{l}7,854 \\
(22.1)\end{array}$ & $\begin{array}{l}3,829 \\
(10.8)\end{array}$ & $\begin{array}{l}1,200 \\
(3.4)\end{array}$ & $\begin{array}{c}90 \\
(0.3)\end{array}$ & 35,479 \\
\hline Idaho & $\begin{array}{l}6,792 \\
(57.5)\end{array}$ & $\begin{array}{l}2,534 \\
(21.5)\end{array}$ & $\begin{array}{l}1,266 \\
(10.7)\end{array}$ & $\begin{array}{c}734 \\
(6.2)\end{array}$ & $\begin{array}{c}480 \\
(4.1)\end{array}$ & 11,806 \\
\hline Missouri & $\begin{array}{l}18,412 \\
(61.4)\end{array}$ & $\begin{array}{l}6,557 \\
(21.9)\end{array}$ & $\begin{array}{l}3,031 \\
(10.1)\end{array}$ & $\begin{array}{l}1,518 \\
(5.1)\end{array}$ & $\begin{array}{c}446 \\
(1.5)\end{array}$ & 29,964 \\
\hline Pennsylvania & $\begin{array}{l}9,665 \\
(56.5)\end{array}$ & $\begin{array}{l}3,911 \\
(22.9)\end{array}$ & $\begin{array}{l}1,958 \\
(11.5)\end{array}$ & $\begin{array}{l}1,083 \\
(6.3)\end{array}$ & $\begin{array}{c}478 \\
(2.8)\end{array}$ & 17,095 \\
\hline Washington & $\begin{array}{l}18,043 \\
(64.3)\end{array}$ & $\begin{array}{l}6,026 \\
(21.5)\end{array}$ & $\begin{array}{c}2,443 \\
(8.7)\end{array}$ & $\begin{array}{l}1,132 \\
(4.0)\end{array}$ & $\begin{array}{c}433 \\
(1.5)\end{array}$ & 28,077 \\
\hline Total $^{\mathrm{a}}$ & $\begin{array}{c}2,213,640 \\
(59.9)\end{array}$ & $\begin{array}{c}825,180 \\
(22.3)\end{array}$ & $\begin{array}{c}394,520 \\
(10.7)\end{array}$ & $\begin{array}{c}192,640 \\
(5.2)\end{array}$ & $\begin{array}{c}71,980 \\
(1.9)\end{array}$ & $3,697,960$ \\
\hline
\end{tabular}

Source: From sample of benefit years with positive benefits paid. See text for details.

a The total is a weighted sum in which each state's count is divided by its sampling rate. giving an estimate of the total for the entire five state population. 


\section{Table 2}

\section{Claim Weighted Distribution of Claims in 5-Year Window (Row Percentages in Parentheses)}

\begin{tabular}{l|ccccc|c}
\hline \multirow{2}{*}{ State } & \multicolumn{5}{|c|}{ Number of Benefit Years Claimed } & \multirow{2}{*}{ Total } \\
\cline { 2 - 6 } Georgia & $I$ & 2 & 3 & +1 & 5 & 54,951 \\
& 22,506 & 15,708 & 11,487 & 4,800 & 450 & \\
Idaho & $(41.0)$ & $(28.6)$ & $(20.9)$ & $(8.7)$ & $(0.8)$ & \\
& 6,792 & 5,068 & 3,798 & 2,936 & 2,400 & 20,994 \\
Missouri & $(32.4)$ & $(24.1)$ & $(18.1)$ & $(14.0)$ & $(11.4)$ & \\
& 18,412 & 13,114 & 9,093 & 6,072 & 2,230 & 48,921 \\
Pennsylvania & $(37.6)$ & $(26.8)$ & $(18.6)$ & $(12.4)$ & $(4.6)$ & \\
& 9,665 & 7,822 & 5,874 & 4,332 & 2,390 & 30,083 \\
Washington & $(32.1)$ & $(26.0)$ & $(19.5)$ & $(14.4)$ & $(7.9)$ & \\
& 18,043 & 12,052 & 7,329 & 4,528 & 2,165 & 44,117 \\
\hline Total & $(40.9)$ & $(27.3)$ & $(16.6)$ & $(10.3)$ & $(4.9)$ & \\
\hline Weeks per Benefit Year $^{\text {a }}$ & 18.40 & 17.63 & 16.29 & 15.96 & 16.22 & 17.35 \\
\$ per Benefit Year (1990 \$) & 3,391 & 3,415 & 3,172 & 2,948 & 2,731 & 3,262 \\
\hline
\end{tabular}

Source: From sample of benefit years with positive benefits paid. Sce text for details.

a The total is a weighted sum in which each state's count is divided by its sampling rate. giving an estimate of the total for the entire five state population. 
Table 3

Spell Weighted Distribution of Spells in 5-Year Window

\begin{tabular}{l|cccccc}
\hline & \multicolumn{7}{|c}{ Number of Spells } \\
\cline { 2 - 7 } & 1 & $2-3$ & $4-6$ & $7-10$ & $11-19$ & 20 \\
\hline Percentage of Spells & 7.0 & 23.0 & 22.6 & 17.6 & 19.6 & 10.2 \\
Weeks per Spell & 14.56 & 10.41 & 8.40 & 5.95 & 4.09 & 2.72 \\
\$ per Spell $(1990 \$)$ & 2,718 & 1,917 & 1,594 & 1,140 & 764 & 418 \\
\hline
\end{tabular}

Source: From sample of UI spells with positive benefits paid. See text for details. 
Table 4

\section{Claim Weighted Distribution of Claims for Those without Long Earnings Gaps and with Adjustment for Chance Repeat Use}

\begin{tabular}{|c|c|c|c|c|c|c|c|}
\hline \multirow[b]{2}{*}{ State } & & \multicolumn{5}{|c|}{ Number of Benefit Years Claimed } & \multirow{2}{*}{$\begin{array}{c}\text { Total } \\
\text { Benefit Years }\end{array}$} \\
\hline & & 1 & 2 & 3 & 4 & 5 & \\
\hline \multirow[t]{3}{*}{ Georgia } & Actual Distribution ${ }^{a}$ & $36.9 \%$ & $29.4 \%$ & $22.9 \%$ & $9.8 \%$ & $0.9 \%$ & 48,120 \\
\hline & Chance Distribution ${ }^{b}$ & $64.1 \%$ & $30.2 \%$ & $5.3 \%$ & $0.4 \%$ & $0.0 \%$ & \\
\hline & Difference $^{c}$ & $-27.2 \%$ & $-0.7 \%$ & $17.6 \%$ & $9.4 \%$ & $0.9 \%$ & \\
\hline \multirow[t]{3}{*}{ Idaho } & Actual Distribution & $27.3 \%$ & $23.2 \%$ & $19.4 \%$ & $16.2 \%$ & $13.8 \%$ & 17,418 \\
\hline & Chance Distribution & $54.8 \%$ & $35.6 \%$ & $8.7 \%$ & $0.9 \%$ & $0.0 \%$ & \\
\hline & Difference & $-27.4 \%$ & $-12.4 \%$ & $10.8 \%$ & $15.3 \%$ & $13.7 \%$ & \\
\hline \multirow[t]{3}{*}{ Missouri } & Actual Distribution & $32.8 \%$ & $26.2 \%$ & $20.5 \%$ & $14.9 \%$ & $5.6 \%$ & 39,783 \\
\hline & Chance Distribution & $63.8 \%$ & $30.4 \%$ & $5.4 \%$ & $0.4 \%$ & $0.0 \%$ & \\
\hline & Difference & $-31.0 \%$ & $-4.2 \%$ & $15.1 \%$ & $14.5 \%$ & $5.5 \%$ & \\
\hline \multirow[t]{3}{*}{ Pennsylvania } & Actual Distribution & $27.1 \%$ & $25.5 \%$ & $20.9 \%$ & $16.9 \%$ & $9.6 \%$ & 24,913 \\
\hline & Chance Distribution & $55.5 \%$ & $35.2 \%$ & $8.4 \%$ & $0.9 \%$ & $0.0 \%$ & \\
\hline & Difference & $-28.4 \%$ & $-9.7 \%$ & $12.5 \%$ & $16.0 \%$ & $9.6 \%$ & \\
\hline \multirow[t]{3}{*}{ Washington } & Actual Distribution & $36.2 \%$ & $27.5 \%$ & $18.3 \%$ & $12.1 \%$ & $5.9 \%$ & 35,153 \\
\hline & Chance Distribution & $60.8 \%$ & $32.2 \%$ & $6.4 \%$ & $0.6 \%$ & $0.0 \%$ & \\
\hline & Difference & $-24.7 \%$ & $-4.7 \%$ & $11.9 \%$ & $11.6 \%$ & $5.9 \%$ & \\
\hline \multirow[t]{3}{*}{ Total $^{d}$} & Actual Distribution & $31.1 \%$ & $26.5 \%$ & $20.8 \%$ & $14.6 \%$ & $7.0 \%$ & $5,126,600$ \\
\hline & Chance Distribution & $59.4 \%$ & $33.0 \%$ & $6.9 \%$ & $0.6 \%$ & $0.0 \%$ & \\
\hline & Difference & $-28.4 \%$ & $-6.5 \%$ & $14.0 \%$ & $13.9 \%$ & $7.0 \%$ & \\
\hline
\end{tabular}

Source: From sample of benefit years with positive benefits paid, excluding persons with four consecutive quarters of zero earnings during the sample period. See text for details.

${ }^{2}$ The actual distribution is the percentages in parentheses in Table 2, but for a sample that excludes persons with four consecutive quarters of zero earnings.

b The chance distribution is the predicted percentages assuming homogeneity and state independence.

c The difference is the difference between the actual and chance distributions.

d The total is a weighted sum in which each state's count is divided by its sampling rate, giving an estimate of the five state total for the entire five state population. 
Table 5

Number of Employers By Number of Benefit Years Claimed (Row Percentages in Parentheses)

\begin{tabular}{l|ccccc|c}
\hline $\begin{array}{l}\text { Number of } \\
\text { Benefit Years }\end{array}$ & \multicolumn{5}{|c|}{ Number of Employers $^{a}$} & \multirow{2}{*}{ Total } \\
\hline 1 & 75,418 & 2 & 3 & 4 & 5 & 75,418 \\
& $(100.0)$ & & & & \\
2 & 12,623 & 12,899 & & & 25,522 \\
3 & $(49.5)$ & $(50.5)$ & & & \\
& 6,126 & 3,543 & 2,293 & & & 11,962 \\
4 & $(51.2)$ & $(29.6)$ & $(19.2)$ & & & \\
& 2,981 & 1,306 & 704 & 449 & & 5,440 \\
5 & $(54.8)$ & $(24.0)$ & $(12.9)$ & $(8.3)$ & & \\
& 1,080 & 500 & 144 & 96 & 41 & 1,861 \\
& $(58.0)$ & $(26.9)$ & $(7.7)$ & $(5.2)$ & $(2.2)$ & \\
\hline
\end{tabular}

Source: From sample of benefit years with positive benefits paid. See text for details.

${ }^{a}$ The numbers given are for the unweighted five state total. The unweighted sample results are similar to those of the weighted sample, while also providing information on cell counts. 
Table 6

The Industry Distribution of UI Recipients:

Percentage of Individuals in each Industry Category

By State and Number of Benefit Years Claimed

\begin{tabular}{|c|c|c|c|c|c|c|c|c|c|c|}
\hline \multirow[b]{2}{*}{ State } & \multirow[b]{2}{*}{$\begin{array}{l}\text { Number of } \\
\text { Benefil Yis. }\end{array}$} & \multicolumn{8}{|c|}{ Industry and 2-Digit SIC Codes } & \multirow[b]{2}{*}{ Total $^{c}$} \\
\hline & & $\begin{array}{l}\text { Agrafin } \\
01-1+\end{array}$ & $\begin{array}{c}\text { Constr } \\
15-19\end{array}$ & $\begin{array}{c}\operatorname{Man} I^{a} \\
20.24\end{array}$ & $\begin{array}{c}1 \tan 2^{6} \\
25-39\end{array}$ & $\begin{array}{c}\text { Tran Com } \\
+0.49\end{array}$ & $\begin{array}{c}\text { Wholest } \\
50-51\end{array}$ & $\begin{array}{l}\text { Retail } \\
52-59\end{array}$ & $\begin{array}{l}\text { Other } \\
60.98\end{array}$ & \\
\hline \multirow[t]{4}{*}{ Georgia } & $0-5$ & 1.37 & 5.92 & 13.38 & 11.74 & $6 .+2$ & 7.34 & 17.99 & 35.84 & $3,792,308$ \\
\hline & 1 & 1.31 & 10.07 & 23.62 & 17.75 & 3.57 & 7.56 & 15.01 & 21.10 & 22,308 \\
\hline & 2 & 0.96 & 10.84 & 40.62 & 22.34 & 2.26 & +.59 & 7.45 & 10.94 & 7,796 \\
\hline & $3-5$ & 0.69 & 7.97 & 56.59 & 23.44 & 1.55 & 2.73 & 2.63 & 4.40 & 5.100 \\
\hline \multicolumn{2}{|l|}{ Seasonality $^{\mathrm{d}}$} & 0.361 & 0.124 & 0.076 & 0.041 & 0.036 & 0.032 & 0.056 & 0.037 & 0.055 \\
\hline \multirow[t]{4}{*}{ Idaho } & $0-5$ & 4.22 & 6.87 & 12.00 & 6.15 & 5.40 & 7.30 & 20.28 & 37.77 & 588,623 \\
\hline & 1 & 5.49 & 12.25 & 15.79 & 8.15 & 5.33 & 9.47 & 21.49 & 22.02 & 6,598 \\
\hline & 2 & 6.29 & 17.88 & 24.89 & 9.68 & 4.84 & 7.62 & 13.88 & 14.91 & 2.489 \\
\hline & $3-5$ & 5.31 & 20.53 & 44.70 & 6.08 & 3.39 & 6.99 & 5.93 & 7.07 & 2.463 \\
\hline \multicolumn{2}{|l|}{ Seasonality } & 0.447 & 0.320 & 0.208 & 0.059 & 0.068 & $0 . \overline{069}$ & 0.118 & 0.056 & 0.128 \\
\hline \multirow[t]{4}{*}{ Missouri } & $0-5$ & 1.33 & 5.10 & 4.45 & 17.18 & 6.75 & 7.82 & 18.64 & 38.74 & $1,245,286$ \\
\hline & 1 & 1.68 & 8.95 & 6.72 & 24.76 & 5.77 & 7.88 & 17.81 & 26.43 & 18.385 \\
\hline & 2 & 2.09 & 14.58 & 10.34 & 34.10 & 4.36 & 5.82 & 12.19 & 16.53 & 6.552 \\
\hline & $3-5$ & 2.69 & 20.94 & 12.92 & 39.63 & 3.90 & +21 & 6.94 & 8.77 & +.992 \\
\hline \multicolumn{2}{|l|}{ Seasonality } & 0.234 & 0.237 & 0.097 & 0.165 & 0.059 & 0.053 & 0.106 & 0.068 & 0.068 \\
\hline \multirow[t]{4}{*}{ Pennsylvania } & $0-5$ & 1.81 & 5.24 & 7.49 & 26.14 & 6.06 & 5.58 & 20.21 & 27.45 & 682,460 \\
\hline & 1 & 2.35 & 6.71 & 9.32 & 32.60 & 4.60 & 5.05 & 16.94 & 22.43 & 9.457 \\
\hline & 2 & 2.95 & 11.03 & 13.41 & +2.81 & 3.54 & 3.71 & 10.46 & 12.09 & 3.871 \\
\hline & $3-5$ & 3.01 & 18.26 & 25.01 & 35.60 & +.08 & 1.84 & 5.50 & 6.69 & 3,502 \\
\hline \multicolumn{2}{|l|}{ Seasonality } & 0.138 & 0.280 & 0.068 & 0.062 & 0.046 & 0.033 & $0 . \overline{062}$ & 0.047 & 0.069 \\
\hline \multirow[t]{4}{*}{ Washington } & $0-5$ & 4.07 & 6.96 & 5.96 & 14.34 & 6.13 & 6.69 & 20.12 & 35.74 & 2.758 .283 \\
\hline & 1 & 3.13 & 11.10 & 8.00 & 17.16 & 4.46 & 8.16 & 20.35 & 27.65 & 17.958 \\
\hline & 2 & 3.60 & 18.88 & 13.07 & 17.96 & 4.94 & 7.04 & 15.07 & 19.46 & 6.004 \\
\hline & $3-5$ & 6.74 & 27.07 & 26.02 & 13.70 & 521 & 6.54 & 6.15 & 8.57 & +.003 \\
\hline \multicolumn{2}{|l|}{ Seasonality } & 0.612 & 0.268 & 0.253 & 0.046 & 0.078 & 0.114 & 0.088 & $0.0+8$ & 0.114 \\
\hline \multirow[t]{4}{*}{ Total $^{e}$} & $0-5$ & 2.06 & 5.69 & 8.11 & 18.69 & 6.26 & 6.63 & 19.41 & 33.13 & \\
\hline & 1 & 2.25 & 8.66 & 11.78 & 24.97 & 4.59 & 6.69 & 17.39 & 23.68 & \\
\hline & 2 & 2.63 & 12.92 & 18.40 & 32.87 & 3.67 & 4.82 & 10.94 & 13.75 & \\
\hline & $3-5$ & 3.14 & 18.23 & 28.94 & 30.55 & 3.77 & 3.10 & 5.37 & 6.89 & \\
\hline \multicolumn{2}{|l|}{ Seasonality } & 0.442 & 0.211 & 0.122 & 0.066 & 0.052 & 0.061 & 0.073 & 0.045 & 0.080 \\
\hline
\end{tabular}

Sources: From sample of benefit years with positive benefits paid and five state sample of quarterly wage records with positive wages received. See text for details.

a The tirst manufacturing category includes tood, tobacco, textiles, apparel, and lumber industries.

b The second manufacturing category includes all of the manufacturing industries not included in the first category

- Due to missing industry values for some observations the row totals do not stm to those in Table 1

d The seasonality measure is the difference in average employment in the best and worst guarters divided by average employment in the 5-year period.

- The total is a weighted sum where ach individual state's coutut is divided by its simpling rate, giving an estimate of the total for the entire tive state population. 
Table 7

Ordered Logit Estimates of the Number of Claims

During 5-Year Window for Persons with a Claim in 1980

\begin{tabular}{|c|c|c|c|c|c|c|c|c|c|c|}
\hline \multirow{4}{*}{$\begin{array}{l}\text { Explanatory } \\
\text { Variable } \\
\end{array}$} & \multirow[b]{4}{*}{ Mean } & \multicolumn{9}{|c|}{ Specification } \\
\hline & & \multicolumn{3}{|c|}{ (1) } & \multicolumn{3}{|c|}{ (2) } & \multicolumn{3}{|c|}{$(3)$} \\
\hline & & & Standard & Discrete & & Standard & Discrete & & Standard & Discrete \\
\hline & & Coefficient & Error & Diff. $(\%)^{a}$ & Coefficient & Error & Diff. $\%$ & Coefficient & Error & Diff. $(\%)$ \\
\hline \multicolumn{11}{|l|}{ Intercepts: } \\
\hline$x_{1}^{b}$ & & 0.464 & 0.073 & 61.40 & 0.561 & 0.085 & 63.68 & 0.574 & 0.111 & 63.96 \\
\hline$\alpha_{2}$ & & -0.801 & 0.073 & 30.97 & -0.699 & 0.085 & 33.20 & -0.713 & 0.111 & 32.90 \\
\hline$\alpha_{3}$ & & -1.873 & 0.074 & 13.32 & -1.768 & 0.086 & 14.58 & -1.816 & 0.112 & 14.00 \\
\hline$\alpha_{4}$ & & -3.309 & 0.077 & 3.53 & -3.223 & 0.090 & 3.83 & $-3,214$ & 0.117 & 3.86 \\
\hline \multicolumn{11}{|l|}{ Background: } \\
\hline Female & 0.340 & 0.042 & 0.036 & 0.91 & -0.126 & 0.056 & -2.71 & -0.092 & 0.074 & -1.97 \\
\hline Married*female & 0.101 & & & & 0.308 & 0.068 & 6.67 & 0.149 & 0.090 & 3.18 \\
\hline Married & 0.627 & & & & 0.020 & 0.042 & 0.43 & 0.061 & 0.054 & 1.31 \\
\hline Nonwhite & 0.216 & 0.123 & 0.045 & 2.68 & 0.191 & 0.053 & 4.16 & 0.099 & 0.077 & 2,11 \\
\hline \multicolumn{11}{|l|}{ Education: } \\
\hline Less than high school & 0.261 & & & & & & & 0.136 & 0.050 & 2.91 \\
\hline Some college & 0.158 & & & & & & & -0.256 & 0.059 & -5.48 \\
\hline College graduate & 0.053 & & & & & & & -0.519 & 0.094 & -11.01 \\
\hline \multicolumn{11}{|l|}{ Age in 1980: } \\
\hline $18-24$ & 0.271 & -0.355 & 0.041 & -7.66 & -0.305 & 0.048 & -6.57 & -0.272 & 0.064 & -5.84 \\
\hline $25-34$ & 0.354 & -0.191 & 0.038 & -4.13 & -0.144 & 0.043 & -3.10 & -0.056 & 0.056 & -1.20 \\
\hline $45-55$ & 0.169 & 0.136 & 0.044 & 2.97 & 0.184 & 0.049 & 4.00 & 0.221 & 0.063 & 4.76 \\
\hline \multicolumn{11}{|l|}{ High Qtr Earnings: ${ }^{\circ}$} \\
\hline Less than $\$ 3,000$ & 0.159 & 0.015 & 0.045 & 0.32 & 0.022 & 0.050 & 0.47 & -0.139 & 0.072 & -2.98 \\
\hline$\$ 5,000-\$ 7,999$ & 0.274 & 0.013 & 0.039 & 0.29 & -0.017 & 0.044 & -0.36 & 0.047 & 0.058 & 1.01 \\
\hline$\$ 8,000$ or more & 0.273 & 0.254 & 0.044 & 5.56 & 0.185 & 0.051 & 4.04 & 0.273 & 0.067 & 5.87 \\
\hline \multicolumn{11}{|l|}{ State: } \\
\hline Idaho & 0.141 & 0.210 & 0.051 & 4.59 & -0.031 & 0.060 & -0.66 & -0.069 & 0.063 & $-1+7$ \\
\hline Missouri $^{d}$ & 0.378 & -0.374 & 0.039 & -8.13 & -0.548 & 0.043 & -11.87 & & & \\
\hline Washington & 0.268 & -0.294 & 0.043 & -6.31 & -0.454 & 0.048 & -9.63 & -0.450 & 0.051 & -9.67 \\
\hline \multicolumn{11}{|l|}{ Claim Date: } \\
\hline April-June & 0.268 & -0.390 & 0.037 & -8.44 & -0.394 & 0.042 & -8.51 & -0.286 & 0.054 & -6.14 \\
\hline July-September & 0.209 & 0.027 & 0.040 & 0.59 & 0.022 & 0.045 & 0.47 & 0.055 & 0.060 & 1.16 \\
\hline October-December & 0.235 & 0.247 & 0.038 & 5.39 & 0.241 & 0.044 & 5.26 & 0.285 & 0.056 & 6.12 \\
\hline
\end{tabular}

(Continued) 


\section{Table 7 \\ Ordered Logit Estimates of the Number of Claims During 5-Year Window for Persons with a Claim in 1980 (Continued)}

\begin{tabular}{|c|c|c|c|c|c|c|c|c|c|c|}
\hline \multirow{4}{*}{$\begin{array}{l}\text { Explanatory } \\
\text { Variable }\end{array}$} & \multirow[b]{4}{*}{ Mean } & \multicolumn{9}{|c|}{ Specification } \\
\hline & & \multicolumn{3}{|c|}{ (1) } & \multicolumn{3}{|c|}{ (2) } & \multicolumn{3}{|c|}{ (3) } \\
\hline & & & Standard & Discrete & & Standard & Discrete & & Standard & Discrete \\
\hline & & Coefficient & Error & Diff. $(\%)^{a}$ & Coefficient & Error & Diff. (\%) & Coefficient & Error & Diff \\
\hline \multicolumn{11}{|l|}{ Industry: } \\
\hline Agr./For./Fishing & 0.017 & 1.567 & 0.111 & 31.65 & 1.637 & 0.128 & 32.89 & 1.719 & 0.154 & 32.36 \\
\hline Mining & 0.011 & 1.265 & 0.137 & 26.33 & 1.310 & 0.151 & 27.22 & 0.959 & 0.202 & 19.67 \\
\hline Construction & 0.171 & 1.321 & 0.059 & 28.10 & 1.394 & 0.067 & 29.51 & 1.259 & 0.090 & 25.93 \\
\hline Food, tobacco & 0.056 & 1.847 & 0.074 & 36.79 & 1.760 & 0.085 & 35.43 & 1.936 & 0.106 & 36.49 \\
\hline Textiles & 0.007 & 1.095 & 0.171 & 23.12 & 0.968 & 0.187 & 20.66 & 0.864 & 0.199 & 17.85 \\
\hline Apparel & 0.049 & 1.700 & 0.085 & 34.08 & 1.657 & 0.094 & 33.58 & 1.709 & 0.126 & 32.65 \\
\hline Lumber & 0.074 & 1.553 & 0.069 & 32.12 & 1.497 & 0.081 & 30.97 & 1.406 & 0.098 & 28.30 \\
\hline Leather & 0.016 & 1.532 & 0.133 & 31.00 & 1.451 & 0.145 & 29.72 & 1.594 & 0.284 & 30.35 \\
\hline Primary Metals/Steel & 0.028 & 0.869 & 0.096 & 18.61 & 0.839 & 0.105 & 18.03 & 0.651 & 0.124 & 13.65 \\
\hline Transportation Equip. & 0.067 & 0.982 & 0.073 & 20.80 & 1.053 & 0.083 & 22.22 & 0.776 & 0.134 & 16.10 \\
\hline Other Manufacturing & 0.159 & 0.714 & 0.057 & 15.09 & 0.736 & 0.064 & 15.56 & 0.601 & 0.090 & 12.54 \\
\hline Transportation/Com. & 0.043 & 0.672 & 0.077 & 14.46 & 0.673 & 0.088 & 14.48 & 0.590 & 0.118 & 12.37 \\
\hline Wholesale Trade & 0.065 & 0.693 & 0.069 & 14.86 & 0.673 & 0.078 & 14.43 & 0.676 & 0.106 & $1+.06$ \\
\hline Retail Trade & 0.112 & -0.028 & 0.061 & -0.60 & -0.021 & 0.068 & -0.45 & -0.052 & 0.091 & -1.11 \\
\hline FIRE & 0.017 & -0.557 & 0.121 & -11.66 & -0.613 & 0.136 & -12.72 & -0.780 & 0.179 & -16.17 \\
\hline Government & 0.011 & -0.157 & 0.138 & -3.38 & -0.137 & 0.156 & -2.93 & 0.123 & 0.205 & 2.62 \\
\hline \multicolumn{11}{|l|}{ Summary Statistics: } \\
\hline \# of Observations & & & 18,206 & & & 14,090 & & & 8.286 & \\
\hline Prob. of $3+$ Ben. Yrs. & & & $44.60 \%$ & & & $44.12 \%$ & & & $48.19 \%$ & \\
\hline -2 Log Likelihood & & & $52,492.40$ & & & $40,486.29$ & & & $24,051.15$ & \\
\hline
\end{tabular}

Source: From sample of benefit years from 1980 with positive benefits paid, excluding observations from Georgia and persons with four consecutive quarters of zero earnings during the 5-year sample period. See text for details.

"The discrete difference column gives the average discrete difference in the probability of experiencing three or more benefit years as the variable in question changes from a zero to a one.

b [:or a white male aged 35-44 with high quarter earnings between $\$ 3,000$ and $\$ 4,999$ (1990 CPI-U), a claim date between January and March, and from the Pennsylvania service sector. In the 2 nd specification this baseline individual is unmarricd: in the 3 rd specification he has only a high school education. The discrete difference column for $\alpha_{i}$ gives the probability of experiencing $(\mathrm{i}+1)$ or more benefit years in the five year sample for a baseline individual with a benefit year in 1980). Iligh quarter earnings are measured in 1990 CPI-U dollars.

${ }^{d}$ In Missouri the education variable was not recorded, so in the third specification Missouri data are not included.

- The probability of $3+$ benefit years is the percentage of 1980 UI recipients with three or more benefit years in the five year sample period. 